\title{
Developments in Tourism Social Science
}

\author{
John Tribe \\ University of Surrey, UK \\ John Tribe is Professor of Tourism at the University of Surrey (Guildford GU2 7XH, \\ United Kingdom. Email<j.tribe@ surrey.ac.uk>). He has authored books on \\ philosophy, strategy, economics, education, research and environmental management \\ and his research concentrates on epistemology, education, and sustainability. He is \\ Editor-in-Chief of Annals and Co-Chair of the UNWTO Education and Science \\ Council and was the tourism expert reviewer for the last UK national research \\ assessment exercise (RAE).
}

Honggen Xiao

The Hong Kong Polytechnic University, Hong Kong

Honggen Xiao is Assistant Professor in the School of Hotel and Tourism Management at The Hong Kong Polytechnic University (Hung Hom, Kowloon, Hong Kong SAR. Email<hmhgxiao@polyu.edu.hk>). His interests include sociology of knowledge, scientific community, learning, cultural studies, and leisure and recreation. He is Calendar and Index Editor of Annals.

\section{INTRODUCTION}

This editorial, which will be a permanent feature in the first issue of each yearly volume of the journal, represents a new initiative for Annals of Tourism Research. Its purpose is to offer a space of reflexivity both about the journal itself and the knowledge which it publishes. It will be presented in two main sections. The first section, titled Journal Developments, offers an update on the journal itself. This will include information about changes to the editorial board, a summary of any changes to the journal's protocols, a commentary on some of the broad data available for the journal and reflections on the journal. The second section, titled Developments in Knowledge, will offer a reflection on recent articles published in the journal. It will 
analyze trends in tourism knowledge published in Annals.

\section{JOURNAL DEVELOPMENTS}

\section{Editorial Changes}

As from January 2008 Jafar Jafari stepped down as Editor-in-Chief of Annals and John Tribe took over this role. Annals has not yet carried a note of appreciation to Dr Jafari and so this is an opportune moment to make a few brief comments. Jafar was the founding editor of Annals and guided the journal from its instigation in 1973 through its first thirty four volumes. Looking back at the first issues shows what incredible progress the journal has made through Jafar's stewardship since these early issues bear almost no resemblance to later issues of the journal. Jafar had the foresight to establish Annals as a social sciences journal in Tourism. But he also demonstrated many other qualities as Editor-in-Chief.

Perhaps the first of these was a meticulous eye for detail, quality and standards. Second was Jafar's ability to assemble such a renowned team of academics to make up the editorial board. He was able to do this through his extensive international personal networks and deep understanding of the extent of the social sciences. Third, Jafar was a most able and efficient administrator of the journal, developing the robust systems that still serve the journal well. Fourth, Jafar was able to engender a huge amount of loyalty and pride in the editorial team, authors and readers. Finally, Jafar instigated the Annals editorial model where a team of specialist resource editors take responsibility for the review and processing of submitted articles. This is a great strength of Annals as it means that editorial power does not rest solely with one person. Rather editorial power is diffused and the system enables a good matching of editorial expertise to the discipline(s) and subjects deployed in papers submitted. But 
perhaps above all it was Jafar's personal touch and philosophy that has made the journal what it is today. Jafar's communications with his editorial team were always efficient and personal. His philosophy was that the journal should uphold the best possible standards whilst at the same time being supportive of its authors. Jafar was fond of saying "we should not be gate closers but gate openers".

These few sentences cannot do full justice to Jafar's contribution, especially through Annals, to the development of Tourism as a serious field of academic study. Over the years he carefully crafted and nurtured the journal, its standards, its culture and its team - so that Annals has become the clear leader and benchmark for journals in this field.

\section{Protocols, Approaches and Journal Structure}

The following are the main recent changes to the protocols of the journal which have been designed to make writing for the journal more streamlined:

1. The journal now uses the Elsevier Electronic Submission (EES) system

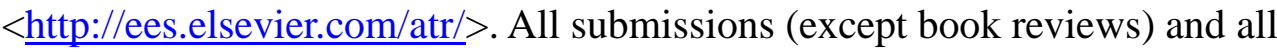
communications between the editorial team and authors now take place using this platform.

2. The need for an abstract in French has been discontinued.

3. The referencing system used by the journal is now the standard American Psychological Association (APA) format. This means that programmes such as Endnote and Reference Manager can be used by article authors to compile reference lists.

As well as these three protocol changes there have been two changes that relate to 
allowable approaches in submitted articles:

1. It was not previously allowed to write an Annals article using the first person. This prohibition has now been lifted with the following proviso. The first person is allowable if the method deployed by the research justifies and explains its use.

2. The acceptability of economics papers in Annals has been debated over the years. Current editorial policy is that economics is a key discipline of the social sciences and therefore such articles are welcome for this journal. This then gives rise to a discussion as to whether such articles should be permitted to use detailed mathematical notation, formulae and equations. The policy here is also now clarified. Most social science disciplines have their specialist languages and approaches. These may not be readily understood outside of the discipline. The same rules should apply to economics articles. Since mathematical notation, formulae and equations form part of the specialist language of economics their use should be permitted even though these may not be readily understood outside of the discipline. To restrict the permissible language of economics articles would restrict the ability of its researchers to advance the frontiers of knowledge. However it is hoped that authors of such articles will attempt to make their findings accessible to a wider audience of social scientists.

Starting with this issue Annals is also embarking upon a series of review papers that clarify the state of the art on key issues (one for each issue). These are invited contributions of around 9000 words from leading experts in the tourism field. They are subject to the regular journal standards of double blind review.

The specification for these articles is as follows: 
1. Essentially they will be state of the art reviews on key issues. Their purpose is:

1.1. to be the key reference for others researching in this area

1.2. to lead new / cutting edge research agendas

2. They might address issues such as:

2.1. critical literature review

2.2. conceptual issues

2.3. methodological issues

2.4. theoretical and practical progress

2.5. synthesis and state of the art

2.6. difficulties and unresolved issues

2.7. relationship to progress in other fields, research agendas etc.

2.8. future research directions

\section{Journal Data}

For the year 2009 Annals recorded a total of 2956 cites with an impact factor of 1.165 , an immediacy index of 0.138 and a cited half life $>10.0$. The impact of Annals is showing an upward trend and this is evident from Table 1.

*** insert table 1 here

The three countries which are the origin of most accepted papers are the United States, the United Kingdom and Australia. The largest increase in accepted papers was recorded for the United States, Cyprus and Canada whilst the largest decrease was from Australia, Hong Kong and Denmark. Table 2 shows the astounding growth in article downloads which have almost doubled between 2006 and 2009. 
*** insert table 2 here

The number of manuscripts submitted to Annals is showing a rising trend. It rose from 253 in 2008 to 261 in 2009 and is likely to be well in excess of 300 for 2010 . Over the past two years the rejection rate for articles ranged from 0.75 to 0.96 .

There are a number of ways of assessing the popularity and the impact of articles published in Annals. Table 3 presents an overview of the most cited articles published in the past 5 years as recorded in Scopus (Andereck et al., 2005; Barros, 2005; Weaver, 2005; Uriely, 2005; Lee et al., 2005; Saarinen, 2006; Pan \& Fesenmaier, 2006;

Reisinger \& Steiner, 2006; Cooper, 2006; Tribe, 2006).

*** insert table 3

Using a different measure of impact, Table 4 presents a summary of the most downloaded papers in Annals (Wang, 1999; Beerli \& Marton, 2004; Chhabra et al., 2003; Gallarza et al., 2002; Waitt, 2003; Miller et al., 2010; Taylor, 2001; Alegre \& Garau, 2010; Smallman \& Moore, 2010; Stone \& Sharpley, 2008).

*** insert table 4

\section{DEVELOPMENTS IN KNOWLEDGE}

The aim of this section is to reflect upon knowledge trends from a social science journal standpoint using published papers as the main point of reference. Such a reflection may hopefully help readers better appreciate patterns and trends created by 
published content in Annals.

As stated in the journal's aims and scope, Annals is a social sciences journal focusing upon the academic perspectives of tourism. It is dedicated to developing theoretical constructs and it expands frontiers of knowledge in and contributes to the literature on tourism social science through both structuring and being structured by multidisciplinary research. Such a mission is clearly reflected in the journal's publication agenda. Major contributions from the last two volumes, 81 main articles in total, can be roughly grouped into subject categories which are set out in the following subsections:

\section{Reflections on Tourism Research and Knowledge Production}

Reflections on tourism studies, its knowledge production and its theoretical state-of-the-art from paradigmatic, methodological and multidisciplinary perspectives have constituted a primary subject area of published articles in recent volumes. These articles are reflected through a number of subject headwords in the journal's cumulative "Subject Index" (<www.elsevier.com/locate/annals $>)$. For example, in the two volume indices (36:771-776 and 37:1230-1236), such headwords, in alphabetic order, are "Communication, research; Community, scientific; Discipline; Education; Epistemology; Ethnography; Knowledge, sociology of; Methodology; Model; Paradigm; Philosophy; Research; Theory; and Tourism, study of". "Multidisciplinary approach" as a headword is also cross-referenced to "Anthropology; Economics; Geography; and Sociology”.

Specifically research on the above subjects is augmented through a series of articles that either directly or indirectly contribute to such reflections and critiques on tourism studies and its knowledge production. For example, Ayikoru, Tribe and Airey 
(2009) examine tourism education and research in light of neo-liberalism, critical theory and the power of knowledge; Belhassen and Caton (2009) adopt a linguistic approach to exploring tourism knowledge progression, which encompasses morphology (or the creation of concepts and models), the production and promotion of new interpretations, and the employment of research to solve problems of (or by) practitioners and policymakers. From a paradigmatic standpoint, critical and hermeneutic/phenomenological approaches to tourism studies are explored by Ren, Pritchard and Morgan (2010), and Pernecky and Jamal (2010). In addition, Tribe (2010) critically analyzes the nature and structure of tourism studies as well as the culture and network practices of its academics. Adopting a social network approach, Racheria and $\mathrm{Hu}$ (2010) examine and report on tourism research collaborations on the basis of co-authorship patterns in the top three tourism journals.

A number of theories or theoretical models are adopted to or applied in tourism. As a relatively new subject in Annals, network or networking is explored both as a theory and a methodological approach in tourism studies. Baggio, Scott and Cooper (2010) present a review and critique on network science in the context of tourism; Paget, Dimanche and Mounet (2010) adopt the actor-network theory to examine innovation in a resort context, which enhances the understanding of tourism business success through reconfiguration of resources to create unique and innovative products. In a different context of alternative tourism, Rodger, Moore and Newsome (2009) use the same theory to describe and analyze the development and decline of scientific research and its impacts on wildlife tourism in the Antarctic, concluding that actor-network theory provides a robust description of the complex role and positioning of science in wildlife tourism.

In addition, collaboration theory is adopted to understand power relations in destination branding (Marzano \& Scott, 2009); self determination theory introduced 
to account for motivation and behavior in tourism consumptions (White \& Thompson, 2009); and social memory theory used to describe the process through which tourism can engage in creating and perpetuating the memories articulated through memorials of previous generations (Winter, 2009). A number of authors have adopted a critical theory approach to the scrutiny of tourism education (Ayikoru, Tribe \& Airey, 2009), tourism research and scholarship (Pernecky \& Jamal, 2010; Ren, Pritchard \& Morgan, 2010), and the sense-making of tourism as an encounter for individuals with vision problems (Richards, Pritchard \& Morgan, 2010). From the consumer behavior perspective, a number studies revisit behavior and choice, as well as logistic models in the tourist decision-making, destination choice, and other tourism behavioral contexts (Cole, 2009; Decrop, 2010; Krider, Arguello, Campbell \& Mora, 2010; Smallman \& Moore, 2010).

In terms of paradigms and research methodology, Annals has maintained its usual mix of innovative methodology, particularly critical, interpretive and constructivist approaches. Apart from five conceptual discussion and review papers, in 76 recent main articles, 45 articles (60\%) adopt qualitative inductive approaches; 21 articles (27\%) present quantitative deductive descriptions; and ten articles (about 13\%) use mixed method approaches. Typical qualitative-inductive approaches in the past two volumes include phenomenology of visitor experience to sacred sites (Andriotis, 2009), visual autoethnography as a method for exploring tourists' experiences (Scarles, 2010), ethnography of rural destination development and change in a critical post-colonial context (Tucker, 2010), and an ethnographical account of transformation and experiential learning of international students through tourism and cross-cultural communication (Brown, 2009). Deductive approaches are exemplified by research on scale development to measure vacation/leisure constraints (Hung \& Petrick, 2010). 


\section{Development, Impact, and Community}

Another major area of published research in the last two volumes relates to subjects such as development, impacts and community, which are also cross-referenced to headwords such as collaboration, planning, policy, poverty, stakeholder, and sustainability. Both general and specific approaches are taken to research into tourism development, impacts and community. For example, Minnaert, Maitland and Miller (2009) report on the value of social tourism in increasing family and social capital and hence its contribution to social policy in European societies. From country specific perspectives, Amuquandoh (2010) examines residents' subjective definitions of tourism and its perceived impacts on development in Ghana. Airey and Chong (2010) report on a study of the key players and institutional processes involved in national tourism policy-making in China. They explore how policy-makers have developed and implemented policy during a period of change in ideologies, organizational values and interest in this fastest growing destination for both international and domestic tourism. Lee, Riley and Hampton (2010) analyze the dynamics of collaboration and political involvement that influences the progress of heritage sites in Korea. Instances of policy implementation, dependency and development in different parts of Thailand are examined by Krutwaysho and Bramwell (2010) and Lacher and Nepal (2010) respectively. In addition, Nyaupane and Timothy (2010) use power relationship frameworks and regionalism concepts to study the political aspects of tourism policy in Bhutan.

With respect to sustainability or sustainable development of tourism in a destination community, Miller, Rathouse, Scarles, Holmes and Tribe (2010) report on a UK-based study to look at public understanding of sustainable tourism with regards to community members' desired goals and expectations about the role of government 
and the industry in fostering sustainable tourism development. Focusing on a tripartite relationship among environment, tourism and the market, Holden (2009) highlights the centrality of the environmental ethics held by the market to achieving a balance in the tourism-environment nexus. Using resilience concepts through a systems thinking approach, Strickland-Munro, Allison and Moore (2010) present a conceptual discussion on assessing the impacts of protected area tourism on communities. Currie, Seaton and Wesley (2009) discuss the usefulness of a systematic stakeholder analysis within a feasibility analysis for a proposed tourism development - a potential land and water trail located on the Northwest Coast of British Columbia, Canada.

Some development studies focus on the role of tourism in rural development and poverty alleviation from a community development perspective. Framed around interaction theory, Matarrita-Cascante (2010) explores community relations by examining the causal factors, processes, and outcomes associated with tourism-led development. Based on instances of Costa Rican communities, his case studies find that factors such as open communication, widespread participation, tolerance, and communion among residents and tourism-related stakeholders are critical to the promotion of processes leading to successful tourism development. Nonetheless, Deller's (2010) US-based rural development study presents findings to the contrary on the role of tourism and recreation in alleviating poverty. The author reports on the insignificant and limited role of tourism in explaining changes in poverty rates across states, and challenges the idea of promoting tourism and recreation as a rural economic development strategy.

\section{Authenticity and Tourist Experience}

A third focus area is authenticity and tourist experience. Topics of published research in this category include tourist experience mediated through videos and/or 
movies, alternative tourism experience, and conceptual discussions on authenticity and tourism experience, among others. For example, Tussyadiah and Fesenmaier (2009) examine the roles of online travel videos as mediators of tourist experiences. They found such videos help provide access to foreign landscapes for potential visitors, or bring back past memories and experiences for prior traveler viewers. Buchmann, Moore and Fisher (2010) report on a case study of Lord of the Rings film-induced tourism to New Zealand, with conceptual discussions relating to object authenticity, existential authenticity, sincerity of relationships and embodied experiences of place. Frost's (2010) analysis of 22 fictional feature movies set and filmed in the Australian Outback provides interesting discussions on how films project the image and attributes of a destination and hence provide a key promise to potential Outback tourists that they will have profound life-changing experiences.

Topics on alternative tourism encompass forms such as volunteer tourism, eco-/nature-based tourism, adventure travel and outdoor recreation, pilgrimage or religious tourism, as well as beach tourism. For example, drawing from interviews and participant observations of eleven volunteer tourists to South Africa, Sin (2009) presents a critical review of volunteer tourism with respect to participants' motivations and performances, and the tensions and paradoxes surrounding volunteer tourism. Rantala's (2010) conceptual investigation of tourist practices focuses on discussions related to pre-reflexivity, orientation towards creative action, and the role of the environment in generating nature-based tourist experience. Informed by extensive participant observations of adventure tourists engaged in rafting and kayaking, Buckley (2010) emphasizes the importance of communications between staff and clients in assuring participants' health, safety and satisfaction in adventurous outdoor recreations, and suggests that communication theories could be tested and augmented in the context of adventure tourism. With respect to religious tourism, 
Collins-Kreiner (2010) looks into the key issues, arguments and conceptualizations on pilgrimage scholarship. A shift to postmodern approaches is discussed in her critique of pilgrimage studies, which is accompanied by features such as expansions of research areas and shifting from differentiation to dedifferentiation, from general/external elements to individual/inner experience, from object/objectivity to subject/subjectivity, and from "either/or" to "both/and" approaches.

Two articles address beach tourism experience. Andriotis (2010) adopts a covert ethnographic approach and reports, through non-participant observations, on a study about deviant behavior in a public nude beach. Baldacchino's (2010) conceptual discussion offers an ontological explanation of the material and cultural aspects of beach tourism and a modern society's fascination with sand and sea.

Two conceptual discussions were published on authenticity. Departing from a social realist perspective, Lau's (2010) revisit of authenticity argues for the notion to be conceptualized solely as object authenticity and de-linked from other concepts such as existential authenticity, which has been discussed in length in tourism studies. Drawing from observations of community-based tourist performances in Papua New Guinea, Martin (2010) discusses the importance of competing claims of authenticity to the understanding of the wider social context and divisions within which tourism is practiced.

In addition, Tsaur, Yen and Chen (2010) explore the conceptualization of independent tourists' knowledge and skills, through the development of a measurement scale with three knowledge constructs: onsite travel capability, pre-trip preparation, and emergency response. A UK-based discussion on social tourism, McCabe's (2009) study evaluates the stated reasons for a holiday among low income families and other groups who experience barriers to participation in tourism. His paper points to the need for more detailed measures of the benefits of tourism and 
calls for wider links to be made between leisure travel experience and social policy agendas.

\section{Typologies of Tourists}

Relating to authenticity and tourist experiences are five articles dealing with the roles or typologies of tourists. As in past volumes, backpackers have remained a popular topic in Annals. Reichel, Fuchs and Uriely (2009) look at Israeli backpackers and their destination choice through structured interviews. Their study finds destination choice is associated with travel motivations, risk perceptions, trip planning, travel arrangements and risk reduction strategies. Enoch and Grossman (2010) examine Israeli and Danish backpackers to India through an interpretive analysis of the blogs or on-line diaries of the backpackers. Reading into the lines of backpackers meeting with a foreign (Indian) culture, the authors find these travel diary writers are distinguishable by behavior in their culture encounters. A cosmopolitan typology comprises those who are willing to engage with members of a different culture whereas a "provincial" or "local" type largely remains rooted in their own culture.

Drawing upon critical social theory on embodiment, Waitt and Duffy (2010) examine attendees of a classical musical festival in Australia. Their article discusses conceptual and methodological implications for researching tourist-oriented festivals and performances when the delivery of experience turns from visual to the audio or listening part of the tourist body. Maoz and Bekerman (2010) present a conceptual argument on postmodern tourists and their experience. Their discussion challenges the traditional etic approach in favor of an emic perspective for the scrutiny of postmodern touristic experience which is often complex, subjective, and full of contradictions. 


\section{Destinations and Attractions}

Destinations and attractions are subjects central to tourism studies. In recent volumes of Annals, a number of articles were published on these subjects. Knight (2010) researches into "wild monkey parks" in Japan—a "contrived" wildlife tourist attraction in a postmodern society where viewing wild animals in their natural habitat is rendered unlikely and impractical in logistic terms. Drawing from observations of South Korean visitors to Australia, Pearce and Kang (2009) look at the effects of prior experience on continuing interest in and future choice decisions about tourist destinations and attractions, with findings contributing to consumer involvement and loyalty theories. Russo and Segre (2009) present a conceptual discussion on how property regimes determine destination structures. The authors conclude with a new tourism research agenda on property rights and destination development.

In addition, Weidenfeld, Williams and Butler (2010) contribute to the literature on knowledge transfer and innovations in the attractions sector. Informed by instances of spatial clustering and product similarity of attractions in Cornwall, England, their study demonstrates that spatial proximity, product similarity and market similarity generally facilitate knowledge transfers and innovation spillovers at both local and regional scales. Rickly-Boyd and Metro-Roland's (2010) comparative study of urban tourists in Budapest, Hungary and rural tourists in Indiana, the United States reveals the prominence of the prosaic in shaping tourists' experiences of a place. The authors argue that while large-scale symbolic elements may draw tourists to a site, it is the everyday features of the landscape working ensemble that shape visitors' impressions of destinations as a place.

\section{Motivation, Behavior and Decision-making}

Tourist motivation, behavior and decision-making have also been a central 
subject in the tourism literature. Building on prior knowledge, a number of articles addressing different aspects of this subject have been published. For example, Wong and Yeh (2009) report on a quantitative investigation, through structural equation modeling, on the relationships between tourists' risk perceptions, tourists' knowledge of a destination and their hesitation in destination decision-making. Their findings suggest that while risk perceptions positively influence hesitation, knowledge of a destination has moderating effects on choice decisions. In a repeat visitation context, Hong, Lee, Lee and Jang (2009) focus on destination decision-making at the group level. They find that while novelty seeking may influence the early stage of a destination decision-making process, it is the influences and constraints amongst members in the group that are key to a final destination choice. The study concludes that repeat visitors are highly likely to choose a final destination through an extended decision making process.

Furthermore, knowledge on tourist satisfaction is augmented by contributions from Alegre and Garau (2010) and Williams and Soutar (2009). The former presents an epistemic and methodological reflection on tourist satisfaction studies, where Alegre and Garau (2010) suggest satisfaction and dissatisfaction experiences of a tourist need to be defined within a specific context of evaluation. In an Australian adventure tourism context, Williams and Soutar (2009) examine the relationships between value, satisfaction, and behavioral intentions, and recommend that tourist satisfaction researchers take a broad and holistic view in the future scrutiny of value and behavioral intentions. Complementary to the above tourist behavioral studies, Lehto, Choi, Lin and MacDermid (2009) empirically assess family functioning on leisure travel, that is, the interplay of family vacation, family cohesion and communication. Their study results reveal that family vacations contribute positively to family bonding, communication and solidarity through different interaction styles 
resulting in distinct types of family vacation behavior (e.g., separated versus connected families, as well as flexible, confused and structured families).

\section{Culture, Heritage and Culture Change}

The use of culture and heritage for tourism and the consequences associated with such use constitutes another major subject area in tourism social sciences research. Using Croatia in the former Yugoslavia as a case for analyzing the implications of manipulating history, Goulding and Domic's (2009) qualitative enquiry identifies rewriting history, identity and otherness, power and control, language and representation of the past, and nostalgia as recurring themes in visitors' perceptions of heritage and history. The paper's conclusion considers the consequences of representing a mono-cultural heritage in a multi-ethnic society.

In the contexts of community heritage and sustainable tourism development, Nicholas, Thapa and Ko (2009) examine residents' support of a world heritage site - The Pitons Management Area on the island of St. Lucia in the Caribbean. The study finds residents' support positively relates to their community attachment and environmental attitudes and is not significantly related to their levels of involvement in heritage site management. Nonetheless, lack of residents' involvement presents critical implications for the sustainability of a community-based heritage tourism site.

Finally, Eriksson's (2010) historical account focuses on Sweden during the interwar years. The paper uses the notions of dirt and cleanliness to examine tourist constructions of differences between themselves and other people, as well as to conceptualize modernity. The author argues that tourist perceptions of cleanliness and dirt can be used to mediate modernity, race, and the authenticity of cultural experiences. 
Representation, Identity, and Image

In indexing Annals, topics such as representation, identity and image are also frequently cross-referenced to subjects such as interpretation, semiotics, and language. Taken together and largely from cultural studies perspectives, these headwords collectively inform a gradually increasing area of tourism research in this journal.

Specifically, in the past two volumes, eight articles contribute to this growing body of knowledge. Raento’s (2009) empirical study of Finnish stamps from 1917-2001 exemplifies the potential of postage stamps as data for tourism studies, the methods of interpretation, and connections to the tourism research literature. The article contributes to discussions on the politics of national identity by offering a critical narrative of the changing relationship between tourism promotion, identity-building, and citizenship education. The representation of culture for tourism is also addressed by Yan and Santos (2009) through a critical discourse analysis of a tourism promotional video, titled "China, Forever". Their analysis demonstrates a conformity of the representation to the Western Orientalistic imagination, as well as the creation of a modern image of China subjugated to Western understanding and authority over modernity. The authors argue that contemporary non-Western tourism discourse recognizes the marketability of Otherness and caters affably to Western tourists through reinventing, reconstructing and renegotiating Chinese identities.

In the same line of discussion, Buzinde and Santos' (2009) interpretation of slavery tourism examines the ways in which tourists decode a former slave plantation by promoting or demoting its cultural authority. The analysis finds tourists interpret the plantation in dichotomous polarized ways based on the meaning structures and knowledge frameworks of the interpretive communities within which they are situated.

Framed within the representation discussions, two articles address tourists' 
reactions to, and their co-construction of, landscape transformation and biophysical and climate changes in coastal destinations (Buzinde, Manuel-Navarrete, Kerstetter \& Redclift, 2010; Buzinde, Manuel-Navarrete, Yoo \& Morais, 2010). In one instance, the analysis of on-site hotel brochures reveals that the industry continues to promote essentialist representations and tourists are increasingly using online networking sites to counter the dominant promotional narratives. In another exploration, these authors adopt a triadic model of social space to inform their discussion on the symbolic meanings of landscapes. Their study sheds light on the complexities involved in a destination's adaptation to landscape transformation and climate change as well as the contested meanings emerged from human-environment relationships.

Building on prior studies on the language of tourism, Pearce (2009) explores tourism humor or roles of humor in tourism settings. His analysis finds that humor often fulfils the roles of promoting visitor comfort, aiding visitor concentration, and establishing social connections and commentary in a tourism setting.

Drawing on culture representation and the national identity of Korea, Park's (2010) study looks at heritage tourism as an emotional journey into nationhood. Drawing from in-depth interviews with tourists and heritage management, the author explores the views of heritage as cultural production and its fundamental role in maintaining national solidarity, with elaborations on how heritage tourism experience acts as a symbolic mechanism through which national belonging can be reconstructed and communicated.

Another type of tourism language is the "holiday talk", through travel story retellings and reminiscence, often heard in ordinary and institutional settings. Using conversation analysis, McCabe and Stokoe (2010) examine the social actions accomplished in (or by) such holiday talk. Their analysis reveals how holiday talk becomes a topic as people organize their lives, activities and social relationships. The 
paper concludes that holiday talk, as everyday social interaction, constitutes an important agenda in tourism social sciences research.

\section{Other Subjects}

A few articles deal with topics not clearly falling under the above subject domains. Due to the scope of Annals as a social sciences journal, some subjects such as industry or industry perspectives, business and operations are not as frequently published in this journal as in other tourism periodicals. Nonetheless, research on such topics also appears in Annals. For example, Wang, Jao, Chan and Chung (2010) explore the intrinsic risks and risk perceptions of Taiwanese tour leaders of group package tours. Their survey research clusters risks by sources into exogenous risks, tourist-induced risks, and tour leader's self-induced risks, and concludes with discussions on academic and managerial implications of understanding risk perceptions for package tour operations.

,There has been an increasing number of contributions from economics or econometric perspectives. For example, departing from conventional economic manipulations, Barros and Machado's (2010) study treats tourist length of stay as a determinant rather than a constraint on destination demand. Their research suggests that length of stay is largely explained by socio-demographic profiles of the tourists, and moderated by perceived characteristics of a destination. Frechtling's (2010) review of Tourism Satellite Accounts (TSA) aims at introducing the non-economic readers to this popular method of measuring economic contributions of tourism to the national economy. His account focuses on TSA concepts, definitions and structure, macroeconomic variables produced, and special cases of accounting for travel agencies and tour operators, business travel consumption, and tourism specific durable goods. The discussion also pinpoints to unresolved future research issues such 
as tourism gross fixed capital formation, tourism collective consumption, and sub-national TSAs. To address long-run tourism demand elasticities, Song, Kim and Yang (2010) introduce a new statistical method called the bias-corrected bootstrap. The authors use this method to analyze demands for Hong Kong tourism,and report on its capacity to provide accurate and reliable confidence intervals for demand elasticities.

In addition, Dickinson, Robbins and Fletcher (2009) adopt a social representation perspective to a study of transport in a rural destination. The authors demonstrate, through the use of social representation principles, how individuals draw on socially accepted explanations of transport where they have little or no direct knowledge or experience of the actual transport modes. The study by Gurel, Altinay and Daniele (2010) relates to tourism education, training and professional development. The authors investigate the relationship between entrepreneurial traits, socio-cultural background and entrepreneurial intention of university students in the United Kingdom and Turkey. The study finds that while education does not seem to play an important role in fostering university students' entrepreneurial traits and intentions, a significant relationship is identified between innovation, propensity to take risks, entrepreneurial families and entrepreneurial intentions.

A study of tourists as targets of crimes is reported by Boakye (2010). With empirical evidence from Ghana, the study explores the degree to which tourist's level of institutionalization (i.e., accommodation preference, reliance on travel intermediaries, and travel party size) influences their suitability for becoming targets of crime in their destination. It is found that tourists' choice of travel options significantly relates to the degree to which they are exposed to crimes. Chang, Kivela and Mak (2010) examine food preferences of Chinese tourists traveling in Australia. Drawing from on-site participant observations and focus group interviews, the authors 
propose a typology to describe and contrast the participants' dining attitudes, motivations and behavior. The study highlights the influence of Chinese food culture on the participants' dining behavior while traveling in overseas destinations.

\section{New Subject Areas}

The introduction of new subject headwords into the comprehensive subject index of Annals is an indication of new knowledge explored or new territories charted in tourism research It is also suggestive of changes in the journal's publishing agenda incorporating subjects that were not previously dealt with due to the journal's publication scope or policy.

In terms of new subjects in 2010 , the following headwords are notable in the Volume Index (37:1230-1236). "Tourism satellite account" is introduced under "Economics"; "geographically weighted regression" under "Methodology, Analytical". For 2009, five new subjects were introduced in the Volume Index (36:771-776). They are: Discourse; Humor; Power; Slavery; and Stamps. These subjects add dimensions to, and expand the domains of, representation and identity, culture and heritage, authenticity and tourist experience, and development and impacts. In addition, the expansion of knowledge on existing subjects in Volume 36 encompasses the following: Knowledge, sociology of; Representation, politics of; Social, tourism; Theory, neoliberalism, self determination, and social memory; and Tour, virtual.

In summary the subject areas of published research in recent volumes of Annals display two characteristics. The first is an interrelatedness of research topics across subject domains. Very often, one article deals with issues crossing two or more subject domains. Second, subject areas are generic and broad, and often of an interdisciplinary nature. Arguably, it is within such interdisciplinary contexts that theories indigenous to tourism are most likely to emerge. In state-of-the-art analyses, 
it is often noted that tourism research is atheoretical and that any theorizing is readily claimed by parent disciplines (Tribe, 2006; Xiao \& Smith, 2006). Looking at these articles under the above-largely trans-disciplinary — knowledge domains, we feel that tourism is gradually evolving from a multidisciplinary endeavor onto an interdisciplinary stage of research and scholarship. We believe that theoretical advancements in tourism are more likely to occur in an interdisciplinary rather than a multidisciplinary state (or stage) of research. As evidenced by published subjects in this social sciences journal, theories indigenous to tourism are possibly more likely to be developed around subjects or problem areas such as tourists and tourist experience; destination and attractions; and tourism-centered development, behavior, representation, and social-cultural change.

\section{CONCLUSION}

Tourism is changing as a field of research and practice. On the one hand, as international and/or cross-border travel develops, new forms of international tourism are challenging the traditional economic and neo-colonial modes of thinking which have for years dominated tourism discourse. On the other hand, the booming of domestic tourism has further blurred its boundaries with recreation, leisure, hospitality, health, and culture and heritage industries in joint pursuits of quality of life and well-being in increasingly service-oriented societies. In response to societal demand for diversity, identity, and sustainability, conventional industries are seeking new ways of growth in the same process of change, where leisure, recreation and tourism are often integrated as alternatives to traditional livelihoods in agriculture or farming, fishery, forestry, mining and manufacturing. Over the last decades, tourism has provided international and geopolitical platforms for the promotion of economic development, world peace, conflict or crisis resolutions, sustainability, poverty 
alleviation, and low carbon lifestyles in response to global warming and climate change. In addition, a community paradigm is gradually establishing itself in tourism policy and planning, and development and operations, where knowledge is contextually mobilized by engaging participants or stakeholders through the nurturing of communities of learning and practice.

In retrospect, it is interesting to ask whether tourism research has reflected such changes. Notably, tourism is no longer a new field of academic endeavor. Nonetheless it is imperative to ask what has been achieved in tourism studies. What is its current state-of-the-art? Where is its future? Are we for example able to discern An Academy of Hope (Ateljevic, Morgan \& Pritchard, 2007), a turn towards Critical Tourism Studies or New Tourism Research (Tribe, 2005)? Or indeed could it be that social science is no longer a useful academic lens or grouping for tourism? The epistemology of tourism is certainly under ever more radical scrutiny and critique as evidenced by Coles et al's (2009) conceptualization of tourism as a post-disciplinary area of study and Hannam's (2009) claim that tourism studies is best approached through nomadology and the mobilities paradigm.

These and similar issues of the frontiers of knowledge in tourism social science will be returned to in future editorials.

\section{REFERENCES}

Airey, D., \& Chong, K. (2010). National policy-makers for tourism in China. Annals of Tourism Research, 37, 295-314.

Alegre, J. \& Garau, J. (2010). Tourist Satisfaction and Dissatisfaction. Annals of 
Tourism Research, 37, 52-73.

Amuquandoh, F. (2010). Lay concepts of tourism in Bosomtwe Basin, Ghana. Annals of Tourism Research, 37, 34-51.

Andereck, K. L., Valentine, K. M., Knopf, R. C., \& Vogt, C. A. (2005). Residents' perceptions of community tourism impacts. Annals of Tourism Research, 32, 1056-1076.

Andriotis, K. (2009). Sacred site experience: A phenomenological study. Annals of Tourism Research, 36, 64-84.

Andriotis, K. (2010). Heterotopic erotic oases: The public nude beach experience. Annals of Tourism Research, 37, 1076-1096.

Ateljevic, I., Morgan, N., \& Pritchard, A. (2007). Editor's introduction: Promoting an academy of hope in tourism enquiry. In I. Ateljevic, A. Pritchard \& N. Morgan (eds.), The critical turn in tourism studies: Innovative research methodologies (pp.1-8). Oxford: Elsevier.

Ayikoru, M., Tribe, J., \& Airey, D. (2009). Reading tourism education: Neoliberalism unveiled. Annals of Tourism Research, 36, 191-221.

Baggio, R., Scott, N., \& Cooper, C. (2010). Network science: A review focused on tourism. Annals of Tourism Research, 37, 802-827.

Baldacchino, G. (2010). Re-placing materiality: A western anthropology of sand. Annals of Tourism Research, 37, 763-778.

Barros, C. P. (2005). Measuring efficiency in the hotel sector. Annals of Tourism Research, 32, 456-477.

Barros, C., \& Machado, L. (2010). The length of stay in tourism. Annals of Tourism Research, 37, 692-706. 
Beerli, A. \& Marton, J. D. (2004). Factors influencing destination image. Annals of Tourism Research, 31, 657-681.

Belhassen, Y., \& Caton, K. (2009). Advancing understandings: A linguistic approach to tourism epistemology. Annals of Tourism Research, 36, 335-352.

Boakye, K. (2010). Studying tourists' suitability as crime targets. Annals of Tourism Research, 37, 727-743.

Brown, L. (2009). The transformative power of the international sojourn: An ethnographic study of the international student experience. Annals of Tourism Research, 36, 502-521.

Buchmann, A., Moore, K., \& Fisher, D. (2010). Experiencing film tourism: Authenticity and fellowship. Annals of Tourism Research, 37, 229-248.

Buckley, R. (2010). Communications in adventure tour products: Health and safety in rafting and kayaking. Annals of Tourism Research, 37, 315-332.

Buzinde, C., \& Santos, C. (2009). Interpreting slavery tourism. Annals of Tourism Research, 36, 439-458.

Buzinde, C., Manuel-Navarrete, D., Kerstetter, D., \& Redclift, M. (2010). Representation and adaptation to climate change. Annals of Tourism Research, 37, 581-603.

Buzinde, C., Manuel-Navarrete, D., Yoo, E., \& Morais, D. (2010). Tourists' perceptions in a climate of change: Eroding destinations. Annals of Tourism Research, 37, 333-354.

Chang, R., Kivela, J., \& Mak, A. (2010). Food preferences of Chinese tourists. Annals of Tourism Research, 37, 989-1011.

Chhabra, D., Healy, R., \& Sills, E. (2003). Staged authenticity and heritage tourism. Annals of Tourism Research, 30, 702-719. 
Cole, S. (2009). A logistic tourism model: Resort cycles, globalization, and chaos. Annals of Tourism Research, 36, 689-714.

Coles, T., Hall, C. M., \& Duval, D. (2009). Post-disciplinary tourism. In J. Tribe (Ed.), Philosophical issues in tourism (pp. 80-100). Bristol: Channel View.

Collins-Kreiner, N. (2010). Researching pilgrimage: Continuity and transformations. Annals of Tourism Research, 37, 440-456.

Cooper, C. (2006). Knowledge management and tourism. Annals of Tourism Research, $33,47-64$.

Currie, R., Seaton, S., \& Wesley, F. (2009). Determining stakeholders for feasibility analysis. Annals of Tourism Research, 36, 41-63.

Decrop, A. (2010). Destination choice sets: An inductive longitudinal approach. Annals of Tourism Research, 37, 93-115.

Deller, S. (2010). Rural poverty, tourism and spatial heterogeneity. Annals of Tourism Research, 37, 180-205.

Dickinson, J., Robbins, D., \& Fletcher, J. (2009). Representation of transport: A rural destination analysis. Annals of Tourism Research, 36, 103-123.

Enoch, Y., \& Grossman, R. (2010). Blogs of Israeli and Danish backpackers to India. Annals of Tourism Research, 37, 520-536.

Eriksson, S. (2010). A rarity show of modernity: Sweden since the 1920s. Annals of Tourism Research, 37, 74-92.

Frechtling, D. (2010). The tourism satellite account: A primer. Annals of Tourism Research, 37, 136-153.

Frost, W. (2010). Life changing experiences: Film and tourists in the Australian outback. Annals of Tourism Research, 37, 707-726.

Gallarza, M. G., Saura, I. G., \& Garcoa, H. C. n. (2002). Destination image: Towards a 
Conceptual Framework. Annals of Tourism Research, 29, 56-78.

Goulding, C., \& Domic, D. (2009). Heritage, identity, and ideological manipulation: The case of Croatia. Annals of Tourism Research, 36, 85-102.

Gurel, E., Altinay, L., \& Daniele, R. (2010). Tourism students' entrepreneurial intentions. Annals of Tourism Research, 37, 646-669.

Hannam, K. (2009). The end of tourism? Nomadology and the mobilities paradigm. In J. Tribe (Ed.), Philosophical issues in tourism (pp. 55-70). Bristol: Channel View.

Holden, A. (2009). The environment-tourism nexus: Influence of market ethics. Annals of Tourism Research, 36, 373-389.

Hong, S., Lee, S., Lee, S., \& Jang, H. (2009). Selecting revisited destinations. Annals of Tourism Research, 36, 268-294.

Hung, K., \& Petrick, J. (2010). Developing a measurement scale for constraints to cruising. Annals of Tourism Research, 37, 206-228.

Knight, J. (2010). The ready-to-view wild monkey: The convenience principle in Japanese wildlife tourism. Annals of Tourism Research, 37, 744-762.

Krider, R., Arguello, A., Campbell, C., \& Mora, J. (2010). Trait and image interaction in ecotourism preference. Annals of Tourism Research, 37, 779-801.

Krutwaysho, O., \& Bramwell, B. (2010). Tourism policy implementation and society. Annals of Tourism Research, 37, 670-691.

Lacher, G., \& Nepal, S. (2010). Dependency and development in northern Thailand. Annals of Tourism Research, 37, 947-968.

Lau, R. (2010). Revisiting authenticity: A social realist approach. Annals of Tourism Research, 37, 478-498.

Lee, C. K., Lee, Y. K., \& Lee, B. (2005). Korea's destination image formed by the 
2002 World Cup. Annals of Tourism Research, 32, 839-858.

Lee, T., Riley, M., \& Hampton, M. (2010). Conflict and progress: Tourism development in Korea. Annals of Tourism Research, 37, 355-376.

Lehto, X., Choi, S., Lin, Y., \& MacDermid, S. (2009). Vacation and family functioning. Annals of Tourism Research, 36, 459-479.

Maoz, D., \& Bekerman, Z. (2010). Searching for Jewish answers in Indian resorts. The postmodern traveler. Annals of Tourism Research, 37, 423-439.

Martin, K. (2010). Living pasts: Contested tourism authenticities. Annals of Tourism Research, 37, 537-554.

Marzano, G., \& Scott, N. (2009). Power in destination branding. Annals of Tourism Research, 36, 247-267.

Matarrita-Cascante, D. (2010). Beyond growth: Reaching tourism-led development. Annals of Tourism Research, 37, 1141-1163.

McCabe, S. (2009). Who needs a holiday? Evaluating social tourism. Annals of Tourism Research, 36, 667-688.

McCabe, S., \& Stokoe, E. (2010). Have you been away? Holiday talk in everyday interaction. Annals of Tourism Research, 37, 1117-1140.

Miller, G., Rathouse, K., Scarles, C., Holmes, K., \& Tribe, J. (2010). Public understanding of sustainable tourism. Annals of Tourism Research, 37, 627-645.

Minnaert, L., Maitland, R., \& Miller, G. (2009). Tourism and social policy. The value of social tourism. Annals of Tourism Research, 36, 316-334.

Nicholas, L., Thapa, B., \& Ko, Y. (2009). Residents' perspectives of a world heritage site: The Pitons management area, St. Lucia. Annals of Tourism Research, 36, $390-412$

Nyaupane, G., \& Timothy, D. (2010). Power, regionalism, and tourism policy in 
Bhutan. Annals of Tourism Research, 37, 969-988.

Paget, E., Dimanche, F., \& Mounet, J. (2010). A tourism innovation case: An actor-network approach. Annals of Tourism Research, 37, 828-847.

Pan, B. \& Fesenmaier, D. R. (2006). Online Information Search: Vacation Planning Process. Annals of Tourism Research, 33, 809-832.

Park, H. (2010). Heritage tourism: Emotional journeys into nationhood. Annals of Tourism Research, 37, 116-135.

Pearce, P. (2009). Now that is funny: Humor in tourism settings. Annals of Tourism Research, 36, 627-644.

Pearce, P., \& Kang, M. (2009). The effects of prior and recent experience on continuing interest in tourist settings. Annals of Tourism Research, 36, 172-190.

Pernecky, T., \& Jamal, T. (2010). (Hermeneutic) Phenomenology of tourism studies. Annals of Tourism Research, 37, 1055-1075.

Racheria, P., \& Hu, C. (2010). A social network perspective of tourism research collaborations. Annals of Tourism Research, 37, 1012-1034.

Raento, P. (2009). Tourism, nation, and the postage stamp: Examples of Finland. Annals of Tourism Research, 36, 124-148.

Rantala, O. (2010). Tourist practices in the forest. Annals of Tourism Research, 37, 249-264.

Reichel, A., Fuchs, G., \& Uriely, N. (2009). Israeli backpackers: The role of destination choice. Annals of Tourism Research, 36, 222-247.

Reisinger, Y. \& Steiner, C. J. (2006). Reconceptualizing object authenticity. Annals of Tourism Research, 33, 65-86.

Ren, C., Pritchard, A., \& Morgan, N. (2010). Constructing tourism research: a critical inquiry. Annals of Tourism Research, 37, 885-904. 
Richards, V., Pritchard, A., \& Morgan, N. (2010). (Re)envisioning tourism and visual impairment. Annals of Tourism Research, 37, 1097-1116.

Rickly-Boyd, J., \& Metro-Roland, M. (2010). Background to the fore: The prosaic in tourist places. Annals of Tourism Research, 37, 1164-1180.

Rodger, K., Moore, S., \& Newsome, D. (2009). Wildlife tourism, science and actor network theory. Annals of Tourism Research, 36, 645-666.

Russo, A., \& Segre, G. (2009). Destination model and property regimes: A exploration. Annals of Tourism Research, 36, 587-606.

Saarinen, J. (2006). Traditions of sustainability in tourism studies. Annals of Tourism Research, 33, 1121-1140.

Scarles, C. (2010). Where words fail, visuals ignite: Opportunities for visual autoethnography in tourism research. Annals of Tourism Research, 37, 905-926.

Sin, H. (2009). Volunteer tourism—“Involve me and I will learn”? Annals of Tourism Research, 36, 480-501.

Smallman, C. \& Moore, K. (2010). Process Studies of Tourists' Decision-Making. Annals of Tourism Research, 37, 397-422.

Song, H., Kim, J., \& Yang, S. (2010). Confidence intervals for tourism demand elasticity. Annals of Tourism Research, 37, 377-396.

Stone, P. \& Sharpley, R. (2008). Consuming dark tourism: A Thanatological Perspective. Annals of Tourism Research, 35, 574-595.

Strickland-Munro, J., Allison, H., \& Moore, S. (2010). Using resilience concepts to investigate the impacts of protected area tourism on communities. Annals of Tourism Research, 37, 499-519.

Taylor, J. P. (2001). Authenticity and sincerity in tourism. Annals of Tourism Research, 
Tribe, J. (2005). New tourism research. Tourism Recreation Research, 30(2), 5-8.

Tribe, J. (2006). The truth about tourism. Annals of Tourism Research, 33, 360-381.

Tribe, J. (2010). Tribes, territories and networks in the tourism academy. Annals of Tourism Research, 37, 7-33.

Tsaur, S., Yen, C., \& Chen, C. (2010). Independent tourist knowledge and skills. Annals of Tourism Research, 37, 1035-1054.

Tucker, H. (2010). Peasant-entrepreneurs: A longitudinal ethnography. Annals of Tourism Research, 37, 927-946.

Tussyadiah, I., \& Fesenmaier, D. (2009). Mediating tourist experience: Access to places via shared videos. Annals of Tourism Research, 36, 24-40.

Uriely, N. (2005). The tourist experience: Conceptual Developments. Annals of Tourism Research, 32, 199-216.

Waitt, G. (2003). Social impacts of the Sydney Olympics. Annals of Tourism Research, $30,194-215$

Waitt, G., \& Duffy, M. (2010). Listening and tourism studies. Annals of Tourism Research, 37, 457-477.

Wang, K., Jao, P., Chan, H., \& Chung, C. (2010). Group package tour leaders’ intrinsic risks. Annals of Tourism Research, 37, 154-179.

Wang, N. (1999). Rethinking authenticity in tourism experience. Annals of Tourism Research, 26, 349-370.

Weaver, D. B. (2005). Comprehensive and minimalist dimensions of ecotourism. Annals of Tourism Research, 32, 439-455.

Weidenfeld, A., Williams, A., \& Butler, R. (2010). Knowledge transfer and innovation 
among attractions. Annals of Tourism Research, 37, 604-626.

White, C., \& Thompson, M. (2009). Self determination theory and the wine club attribute formation process. Annals of Tourism Research, 36, 561-586.

Williams, P., \& Soutar, G. (2009). Value, satisfaction and behavioral intentions in an adventure tourism context. Annals of Tourism Research, 36, 413-438.

Winter, C. (2009). Tourism, social memory and the Great War. Annals of Tourism Research, 36, 607-626.

Wong, J., \& Yeh, C. (2009). Tourist hesitation in destination decision making. Annals of Tourism Research, 36, 6-23.

Xiao, H., \& Smith, S. (2006). Case studies in tourism research: A state-of-the-art analysis. Tourism Management, 27, 803-814.

Yan, G., \& Santos, C. (2009). "China, Forever”: Tourism discourse and self-orientalism. Annals of Tourism Research, 36, 295-315. 
Table 1 Bibliometric data

\begin{tabular}{lcccc}
\hline Year & Total cites & Impact factor & Immediacy index & Cited half-life \\
\hline 2006 & 1060 & 0.543 & 0.058 & 9.3 \\
2007 & 1177 & 0.864 & 0.111 & 9.3 \\
2008 & 1801 & 1.104 & 0.02 & 9.9 \\
2009 & 2956 & 1.165 & 0.138 & $>10.0$ \\
\hline
\end{tabular}

Table 2 Article downloads

\begin{tabular}{lcccc}
\hline Year & $\mathbf{2 0 0 6}$ & $\mathbf{2 0 0 7}$ & $\mathbf{2 0 0 8}$ & $\mathbf{2 0 0 9}$ \\
Downloads & 451969 & 551030 & 694544 & 810762 \\
\hline
\end{tabular}


Table 3 Top 10 cited (articles published in the last five years) Extracted from Scopus (on Wednesday 27 October 2010)

\begin{tabular}{|c|c|}
\hline Cites & Article \\
\hline \multirow[t]{3}{*}{42} & Measuring efficiency in the hotel sector \\
\hline & Volume 32, Issue 2, 2005, Pp 456-477 \\
\hline & Barros, C.P. \\
\hline \multirow[t]{3}{*}{38} & $\underline{\text { Residents' perceptions of community tourism impacts }}$ \\
\hline & Volume 32, Issue 4, 2005, Pp 1056-1076 \\
\hline & Andereck, K.L. | Valentine, K.M. | Knopf, R.C. | Vogt, C.A. \\
\hline \multirow[t]{3}{*}{34} & Comprehensive and minimalist dimensions of ecotourism \\
\hline & Volume 32, Issue 2, 2005, Pp 439-455 \\
\hline & Weaver, D.B. \\
\hline \multirow[t]{3}{*}{34} & The tourist experience. Conceptual developments \\
\hline & Volume 32, Issue 1, 2005, Pp 199-216 \\
\hline & Uriely, N. \\
\hline \multirow[t]{3}{*}{32} & Korea's destination image formed by the 2002 World Cup \\
\hline & Volume 32, Issue 4, 2005, Pp 839-858 \\
\hline & Lee, C.-K. | Lee, Y.-K. | Lee, B. \\
\hline \multirow[t]{3}{*}{31} & Traditions of sustainability in tourism studies \\
\hline & Volume 33, Issue 4, 2006, Pp 1121-1140 \\
\hline & Saarinen, J. \\
\hline \multirow[t]{3}{*}{31} & Online Information Search. Vacation Planning Process \\
\hline & Volume 33, Issue 3, 2006, Pp 809-832 \\
\hline & Pan, B. | Fesenmaier, D.R. \\
\hline \multirow[t]{3}{*}{31} & $\underline{\text { Reconceptualizing object authenticity }}$ \\
\hline & Volume 33, Issue 1, 2006, Pp 65-86 \\
\hline & Reisinger, Y. | Steiner, C.J. \\
\hline \multirow[t]{3}{*}{31} & $\underline{\text { Knowledge management and tourism }}$ \\
\hline & Volume 33, Issue 1, 2006, Pp 47-64 \\
\hline & Cooper, C. \\
\hline \multirow[t]{3}{*}{25} & The truth about tourism \\
\hline & Volume 33, Issue 2, 2006, Pp 360-381 \\
\hline & Tribe, J. \\
\hline
\end{tabular}


Table 4 Most downloaded articles in Annals (on Sunday 31 October 2010)

\begin{tabular}{|c|c|}
\hline Rank & Article \\
\hline \multirow[t]{2}{*}{1.} & $\underline{\text { Rethinking authenticity in tourism experience }}$ \\
\hline & Annals of Tourism Research, Volume 26, Issue 2, April 1999, Pages 349-370 \\
\hline \multirow[t]{2}{*}{2.} & Factors influencing destination image \\
\hline & Annals of Tourism Research, Volume 31, Issue 3, July 2004, Pages 657-681 \\
\hline \multirow[t]{2}{*}{3.} & $\underline{\text { Staged authenticity and heritage tourism }}$ \\
\hline & Annals of Tourism Research, Volume 30, Issue 3, July 2003, Pages 702-719 \\
\hline \multirow[t]{2}{*}{4.} & Destination image - Towards a Conceptual Framework \\
\hline & Annals of Tourism Research, Volume 29, Issue 1, January 2002, Pages 56-78 \\
\hline \multirow[t]{2}{*}{5.} & Social impacts of the Sydney Olympics \\
\hline & Annals of Tourism Research, Volume 30, Issue 1, January 2003, Pages 194-215 \\
\hline \multirow[t]{2}{*}{6.} & $\underline{\text { Public understanding of sustainable tourism }}$ \\
\hline & Annals of Tourism Research, Volume 37, Issue 3, July 2010, Pages 627-645 \\
\hline \multirow[t]{2}{*}{7.} & Authenticity and sincerity in tourism \\
\hline & Annals of Tourism Research, Volume 28, Issue 1, January 2001, Pages 7-26 \\
\hline \multirow[t]{2}{*}{8.} & $\underline{\text { Tourist Satisfaction And Dissatisfaction }}$ \\
\hline & Annals of Tourism Research, Volume 37, Issue 1, January 2010, Pages 52-73 \\
\hline \multirow[t]{2}{*}{9.} & Process Studies Of Tourists Decision-Making \\
\hline & Annals of Tourism Research, Volume 37, Issue 2, April 2010, Pages 397-422 \\
\hline \multirow[t]{2}{*}{10.} & Consuming dark tourism: A Thanatological Perspective \\
\hline & Annals of Tourism Research, Volume 35, Issue 2, April 2008, Pages 574-595 \\
\hline
\end{tabular}

